\title{
T cell Activation does not drive CD4 decline in longitudinally followed HIV-infected Elite Controllers
}

\author{
Philomena Kamya ${ }^{1,2}$, Christos M Tsoukas ${ }^{1,2,3}$, Salix Boulet ${ }^{1,2}$, Jean-Pierre Routy ${ }^{1,2,4}$, Réjean Thomas ${ }^{5}$, Pierre Côté $^{6}$, \\ Mohamed-Rachid Boulassel ${ }^{4}$, Bernard Lessard ${ }^{6}$, Rupert Kaul ${ }^{7}$, Mario Ostrowski ${ }^{7}$, Colin Kovacs ${ }^{8}$, Cecile L Tremblay ${ }^{9}$ \\ and Nicole F Bernard ${ }^{1,2,3^{*}}$
}

\begin{abstract}
Background: Elite controllers (EC) are a rare subset of HIV infected individuals who control viral load below 50 copies/ml of plasma without treatment.

Methods: Thirty four EC were studied. The slope of CD4 count change was available for 25 of these subjects. We assessed immune activation by measuring the percent of $C D 38^{+} H L A-D R^{+} C D 8^{+} T$ cells in the EC group and comparing it with that in 24 treatment-naive HIV disease progressors and 13 HIV uninfected healthy controls.

Results: Compared to HIV uninfected subjects, EC had higher percentages of $C D 38^{+} H L A-D R^{+} C D 8^{+} T$ cells $(p<0.001)$ that was lower than that observed in progressors $(p<0.01)$. Fifteen of $25 E C$ had a slope of CD4 count change that was not significantly different from 0 while 3 had a positive and 7 a negative CD4 count slope. Immune activation did not distinguish EC subsets with stable/increasing versus declining CD4 counts.
\end{abstract}

Conclusions: Elevated immune activation in ECs is not associated with a faster rate of CD4 decline

Keywords: HIV infection, Elite controllers, activation markers, CD4 count change

\section{Introduction}

Untreated HIV infection is usually characterized by viral replication and chronic generalized immune activation, which is thought to be an important driver of CD4 decline in HIV infection [1-6]. Markers of immune activation such as CD38 can be found on a high proportion of the $\mathrm{CD} 8^{+} \mathrm{T}$ cells in HIV infected individuals. CD38, an ectoenzyme involved in transmembrane signaling and cell adhesion, is ubiquitous in its distribution among cells of the immune system and is a marker of both activation and differentiation [7]. HLA-DR is a human major histocompatability complex (MHC) class II antigen that is expressed on macrophages, monocytes, $\mathrm{B}$ cells and on activated $\mathrm{T}$ and NK cells. The co-expression of CD38 and HLA-DR on CD8 ${ }^{+} \mathrm{T}$ cells has been used to detect immune activation in HIV infected

\footnotetext{
* Correspondence: nicole.bernard@mcgill.ca

'Research Institute of the McGill University Health Centre, Montréal, Québec, Canada

Full list of author information is available at the end of the article
}

individuals with low-level viremia and to distinguish populations that spontaneously control VL from those successfully treated with anti-retroviral drugs $[8,9]$.

While stimulation of the immune system by HIV likely induces anti-viral immunity that plays a role in suppression of viral replication, chronic immune activation of non HIV-specific T cells reflects rapid cell turnover due to increased expansion and contraction of antigen stimulated $\mathrm{T}$ cell clones [2]. This process leads to $\mathrm{CD} 4^{+} \mathrm{T}$ cell depletion and immune exhaustion $[4,8,10]$.

Less than $1 \%$ of those infected with HIV maintain VL below the level measured by standard assays, i.e $<50$ copies/ml plasma, long term without treatment and are called Elite Controllers (EC) or Elite Suppressors [10-15]. Despite VL control some EC have low or declining CD4 counts $[8,9,14,16,17]$.

Here, we assessed the percent of $\mathrm{CD} 38^{+} \mathrm{DR}^{+} \mathrm{CD} 8^{+} \mathrm{T}$ cells in $34 \mathrm{EC}$ and compared these values to that seen in chronically infected HIV progressors and uninfected 
healthy controls. For 25 EC there were a sufficient number of longitudinally collected CD4 count determinations to calculate the annual rate of CD4 count change. Since immune activation is implicated in HIV disease progression and varied among EC, we questioned whether EC with stable or increasing CD4 counts would have lower immune activation levels than those with declining CD4 counts.

We confirmed previous studies reporting abnormally high immune activation levels among EC compared to healthy uninfected controls and lower levels than seen is HIV infected progressors in the chronic phase of infection $[8,18,19]$. We found that that immune activation measures were similar in EC with stable/increasing versus declining CD4 counts.

\section{Materials and methods Study population}

The study population included 58 untreated HIVinfected individuals (34 EC, 24 progressors) and 13 HIV-negative healthy controls. Informed consent was obtained from all participants and the research conformed to all ethical guidelines of the participating institutions. 28 EC were recruited from the Canadian Cohort of HIV Infected Slow Progressors, which recruits HIV-infected individuals from several community and university-based hospital clinical centres in Canada; six were from a cohort of HLA-B*57 positive EC followed at the National Institutes of Health [12]. EC were defined as having HIV RNA levels below the level of detection by an ultrasensitive VL assay $(<50$ copies $/ \mathrm{mL})$ on at least 3 occasions for at least 1 year. VL was undetectable at the time point immune activation was assessed. HIV disease progressors were infected for at least 1 year with evidence of declining $\mathrm{CD} 4^{+} \mathrm{T}$ cell counts that fell below 500 cells $/ \mathrm{mm}^{3}$ and VL $>10,000$ copies $/ \mathrm{ml}$. None of the study subjects had evidence of concurrent infections at the time immune activation was assessed. For comparison, 13 healthy uninfected controls were also studied.

\section{Laboratory testing}

Plasma viremia was measured using the Versant HIV-1 3.0 RNA assay (bDNA) (Bayer Diagnostics, Tarrytown, NY) with a detection limit of $50 \mathrm{HIV-1}$ RNA copies/ml of plasma.

\section{Cells}

Blood was obtained by either venipuncture into tubes containing EDTA anticoagulant or by leukapheresis as previously described [20]. Peripheral blood mononuclear cells (PBMCs) were isolated by density gradient centrifugation (Ficoll-paque, Pharmacia Uppsala, Sweden) and cryopreserved in $10 \%$ dimethlyl sulfoxide (DMSO, Sigma-Aldrich, St- Louis, MO) 90\% fetal bovine serum (FBS, Medicorps, Montreal, Quebec, Canada).

\section{Flow Cytometry}

Activation marker expression levels on $\mathrm{T}$ cells was measured on thawed PBMCs that were at least $80 \%$ viable by staining with fluorescein isothiocyanate (FITC) conjugated anti-CD8, phycoerythrin (PE) conjugated antiCD38, allophycocyanin (APC) conjugated anti-HLA-DR, and peridinin chlorophyll protein (PerCP) anti-CD3 antibodies (BD Biosciences, Mississauga, Canada) for $30 \mathrm{~min}$ utes in the dark. In parallel, control samples were stained with PE- and APC-conjugated immunoglobulin isotype control antibodies (BD Biosciences) and used to set gates for defining positive staining. Analysis was performed on a FACSCalibur instrument (BD Biosciences). At least 100,000 events were acquired and analyzed using FlowJo software, version 8.8 (Tree Star, Inc, Ashland OR).

\section{Statistics}

GraphPad Prism software version 4.0a was used for graphical presentation and GraphPad InStat version 3.06 for statistical analysis. Mann-Whitney and Kruskal-Wallis tests with Dunn's multiple post-test comparisons were used to assess the significance of between group differences for comparisons of 2 and more than 2 groups, respectively. Linear regression was used to calculate CD4 count change. P-values $<0.05$ were considered significant.

\section{Results}

\section{Study population}

Table 1 provides information on age, CD4 count, CD8 counts and $\log _{10} \mathrm{VL}$ at the time at which percent CD38 ${ }^{+} \mathrm{DR}^{+} \mathrm{CD} 8^{+} \mathrm{T}$ cells were assessed for each of the EC participants included in this study. It also presents information on the number of CD4 count assessment and follow up time used to calculate annual rate of CD4 count change with $95 \%$ confidence intervals (CI). In most cases the duration of follow up for CD4 counts and that for virological assessments was the same. Only one subject, EC 11 who was followed for more than 16 years, lost viral control 9 years into follow up. All the other EC subjects maintained $\mathrm{VL}<50$ copies $/ \mathrm{ml}$ of plasma throughout follow up. Table 2 compares the gender composition, median (range) age, CD4 count, CD8 count, $\log _{10} \mathrm{VL}$ and duration of infection for the EC group with that of 24 HIV infected progressors. The ECs and progressor groups were similar to each other in age and absolute CD8 T cell counts ( $\mathrm{p}>0.05$; MannWhitney test). As expected based on the criteria used to define the study populations, EC had significantly lower $\log _{10} \mathrm{VL}$ and higher absolute CD4 counts compared to progressors at the time of immune activation assessment ( $\mathrm{p}<0.05$ for both comparisons; Mann-Whitney test). EC were infected for longer than progressors $(\mathrm{p}<0.05$; Mann Whitney test). The control group of 13 healthy controls included 9 males and 4 females aged a median (range) of $27(23,51)$ yrs. 
Table 1 Elite Controller Study Population Characteristics

\begin{tabular}{|c|c|c|c|c|c|c|c|c|c|}
\hline $\begin{array}{l}\text { Subject } \\
\text { ID }\end{array}$ & Gender $^{1}$ & $\mathrm{Age}^{2}$ & $\mathrm{CD}^{3}$ & $\mathrm{CD}^{3}$ & $\begin{array}{c}\text { Duration of } \\
\text { infection }^{2}\end{array}$ & $\begin{array}{c}\text { \%CD38+DR } \\
+ \text { CD8+ } \\
\end{array}$ & $\begin{array}{c}\text { Duration CD4 FUP/VL } \\
\text { control }^{2,3}\end{array}$ & $\begin{array}{c}\text { \#CD4 } \\
\text { assessments }\end{array}$ & $\begin{array}{c}\text { Annual Rate of CD4 } \\
\text { decline }^{4}\end{array}$ \\
\hline EC 1 & M & 37 & 680 & 680 & 1 & 14.60 & 2.91 & 8 & $9.4(-55.9,74.8)$ \\
\hline EC 2 & M & 31 & 715 & 384 & 5 & 5.42 & 5.14 & 11 & $-17.7(-56.2,20.8)$ \\
\hline EC 3 & M & 68 & 660 & 1082 & 4 & 3.59 & 5.16 & 17 & $6.19(-14.5,26.7)$ \\
\hline EC 4 & $\mathrm{~F}$ & 58 & 714 & 714 & 4 & 4.68 & 5.77 & 14 & $-6.73(-50.7,37.2)$ \\
\hline EC 5 & M & 53 & 310 & 730 & 6 & 3.95 & 5.27 & 14 & $-52.6(-76.6,28.5)$ \\
\hline EC 6 & $\mathrm{~F}$ & 46 & 720 & 631 & 11 & 6.63 & 8.75 & 25 & $-7.4(-22.7,8.0)$ \\
\hline EC 7 & M & 37 & 1040 & 1095 & 11 & 4.33 & 9.64 & 22 & $14.4(-6.5,35.3)$ \\
\hline EC 8 & $\mathrm{~F}$ & 40 & 737 & 303 & 12 & 7.11 & $12.08 / 14.52$ & 22 & $-44.2(-58.0,-30,4)$ \\
\hline EC 9 & M & 53 & 800 & 288 & 10 & 7.35 & 14.88 & 35 & $15.9(10.3,21.6)$ \\
\hline EC 10 & M & 45 & 1050 & 1296 & 20 & 7.41 & 12.27 & 22 & $-11.2(-27.9,5.4)$ \\
\hline EC 11 & M & 39 & 689 & 455 & 9 & 10.20 & 16.78/9.12 & 86 & $-48.9(-59.2,-38.6)$ \\
\hline EC 12 & $\mathrm{~F}$ & 33 & 728 & 434 & 10 & 2.36 & 17.30 & 79 & $-49.2(-53.4,-45.0)$ \\
\hline EC 13 & M & 47 & 770 & 1130 & 19 & 12.70 & $20.02 / 21.63$ & 17 & $-33.0(-50.6,-15.3)$ \\
\hline EC 14 & M & 31 & 928 & 1566 & 2 & 20.00 & 2.75 & N.A. & N.A. ${ }^{5}$ \\
\hline EC 15 & $\mathrm{~F}$ & 31 & 442 & 816 & 2 & 12.40 & 4.75 & 4 & $15.8(-19.3,50.9)$ \\
\hline EC 16 & $\mathrm{~F}$ & 60 & 800 & 1026 & 13 & 3.00 & 13.64 & 8 & $-5.3(-58,7,58.0)$ \\
\hline EC 17 & M & 40 & 460 & 307 & 4 & 6.35 & 3.87 & 10 & $4.3(-40.9,49.6)$ \\
\hline EC 18 & M & 42 & 870 & 551 & 1 & 8.27 & 1.50 & N.A. & N.A. \\
\hline EC 19 & $F$ & 30 & 692 & 627 & 6 & 10.10 & 2.17 & 6 & $-17.0(-121.5,87.5)$ \\
\hline EC 20 & $F$ & 40 & 576 & 498 & 12 & 20.20 & $15.18 / 15.73$ & 13 & $-30.9(-50.2,-11.7)$ \\
\hline EC 21 & M & 36 & 343 & 804 & 14 & 12.20 & 1.05 & N.A. & N.A. \\
\hline EC 22 & M & 61 & 670 & 540 & 4 & 12.5 & 4.62 & 11 & $32.1(-27.3,91.5)$ \\
\hline EC 23 & M & 53 & 740 & 820 & 11 & 33.2 & 18.01 & 16 & $-15.1(-33.3,3.0)$ \\
\hline EC 24 & M & 41 & 978 & 787 & 1 & 37.3 & 11.24 & 29 & $-16.0(-27.6,-4.4)$ \\
\hline EC 25 & M & 55 & 990 & 680 & 10 & 15.3 & 9.48 & 16 & $-29.0(-70.5,12.5)$ \\
\hline EC 26 & M & 68 & 970 & 400 & 17 & 17.5 & 13.18 & 19 & $14.5(3.8,25.2)$ \\
\hline EC 27 & M & 41 & 1200 & 860 & 11 & 13.9 & 12.39 & 34 & $28.6(7.4,49.7)$ \\
\hline EC 28 & M & 48 & 700 & 920 & 8 & 35.4 & 17.20 & 35 & $-1.4(-5.0,2.1)$ \\
\hline EC 29 & $F$ & 53 & 499 & 202 & 8 & 28.9 & N.A. & N.A. & N.A. \\
\hline EC 30 & M & 40 & 510 & 1286 & 14 & 21.5 & N.A. & N.A. & N.A. \\
\hline EC 31 & $\mathrm{~F}$ & 47 & 485 & 277 & 20 & 17.3 & N.A. & N.A. & N.A. \\
\hline EC 32 & $\mathrm{~F}$ & 56 & 865 & 388 & 15 & 20.7 & N.A. & N.A. & N.A. \\
\hline EC 33 & $\mathrm{~F}$ & 56 & 1488 & 1012 & 17 & 2.39 & N.A. & N.A. & N.A. \\
\hline EC 34 & M & 56 & 801 & 713 & 18 & 20.7 & N.A. & N.A. & N.A. \\
\hline
\end{tabular}

${ }^{1} \mathrm{M}=$ male; $\mathrm{F}=$ female

2 years.

${ }^{3}$ The duration of CD4 follow up/duration of viral load control if different from duration of CD4 follow up.

${ }^{4}$ cells $/ \mathrm{mm}^{3}$ (95\% confidence intervals).

${ }^{5}$ Not available (insufficient information available to calculate a slope of CD4 counts change).

Assessment of immune activation in HIV-infected EC, progressors and healthy controls

To address the reproducibility of the assessment of percent $\mathrm{CD}_{38}{ }^{+} \mathrm{DR}^{+} \mathrm{CD}^{+} \mathrm{T}$ cells we tested 6 time points from the same HIV positive treatment naïve $\mathrm{EC}$ individual in duplicate on 2 occasions. The average intra- and inter-assay coefficients of variation $(\mathrm{CV})$ were $3.7 \%$ and $12.62 \%$, respectively. The CV for this measure determined 6 times over 3 years of follow up was 14.9\%. In contrast, the $\mathrm{CV}$ for percent $\mathrm{CD} 38^{+} \mathrm{DR}{ }^{+} \mathrm{CD} 8^{+} \mathrm{T}$ cells

Table 2 Study population descriptive statistics

\begin{tabular}{|c|c|c|c|c|c|c|}
\hline HIV-infected group & Age (yrs) ${ }^{1}$ & Gender (M/F) & CD4 count $^{1,2}$ & CD8 count ${ }^{1,2}$ & $\log _{10} V^{1}$ & 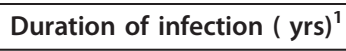 \\
\hline$E C(n=34)$ & $40(30-68)$ & $19 / 8$ & 755 (310-1488) & $696(202-1286)$ & $1.70(1.70-1.70)$ & $12.17(1-20)$ \\
\hline Progressors $(n=24)$ & $36(24-52)$ & $22 / 3$ & $314(191-480)$ & $710(113-2260)$ & $4.29(2.51-5.91)$ & $2(2-12)$ \\
\hline
\end{tabular}

$\mathrm{M}=$ Male, $\mathrm{F}=$ Female, $\mathrm{EC}=$ Elite Controllers.

1 = Median (range).

${ }^{2}=$ cells $/ \mathrm{mm}^{3}$. 
observed among the individuals in the EC and progressor groups was $67.5 \%$ and $65.4 \%$, respectively. Therefore, the intra- and inter-assay variability for assessment of this immune activation parameter did not exceed $13 \%$ providing a measure of the reproducibility of this immune activation parameter within and between experiments. The variability of this immune activation marker within a study subject followed 6 times over 3 years was less than the variability observed among unrelated HIV infected EC or progressors confirming the notion of an immune activation set point introduced by Deeks et al [10].

Figure 1 shows a scatter plot displaying the distribution of the percent of $\mathrm{CD} 38^{+} \mathrm{DR}^{+} \mathrm{CD} 8^{+} \mathrm{T}$ cells in the 3 study groups. Healthy controls, EC and HIV infected progressors had a median (range) of percent $\mathrm{CD} 38^{+} \mathrm{DR}$ ${ }^{+} \mathrm{CD}^{+} \mathrm{T}$ cells of $2.83(0.9,7.3), 12.6(2.3,37.3)$ and 39.8 $(2.87,77.4)$, respectively. Levels of this marker were significantly higher in EC than in healthy controls and lower than in progressors ( $\mathrm{p}<0.01$ and $\mathrm{p}<0.001$ for both comparisons; Dunn's multiple comparisons test).

EC with declining CD4 counts do not have higher levels of percent $C D 38^{+} \mathrm{DR}^{+} \mathrm{CD} 8^{+} \mathrm{T}$ cells than those with stable/ increasing CD4 counts

Previous studies have proposed immune activation to be an important driver of CD4 decline [2,21]. Twenty-five EC were followed longitudinally for a minimum of 2 years with at least 4 CD4 count determinations. We used this information to calculate their annual rate of CD4 count change. The median (range) number of CD4 determinations per subject was $18(4,86)$ taken over 10 $(1,20)$ yrs. Overall, the rate of CD4 count change was -6.04 (-48.9, 32.1) (Table 1). Since longitudinal CD4 count determinations for any one patient are not linear and biological fluctuations in CD4 count occur, leading to wide 95\% CI for CD4 count slopes within any given patient, we categorized all CD4 count slopes having a 95\% CI that crossed zero as not significantly different from zero or stable. According to this criterion 15 EC had stable CD4 count slopes, 3 had CD4 count slopes that increased and 7 that declined significantly. Figure 2 shows graphs plotting the CD4 count change for the 10 subjects with either increasing (Figure 2A) or decreasing (Figure 2B) annual CD4 slopes. Since the EC group described here exhibited higher immune activation levels than healthy controls, we questioned whether EC with declining CD4 counts would have higher immune activation levels than those with stable or increasing CD4 count slopes. The percent of $\mathrm{CD} 38^{+} \mathrm{DR}^{+} \mathrm{CD} 8^{+} \mathrm{T}$ cells for $\mathrm{EC}$ with declining and stable/increasing CD4 count slopes was $8.8(3,35.4)$ and $10.2(2.4,37.3)(\mathrm{p}=0.92$, Mann-Whitney test) (Figure 3). Therefore, EC with falling $\mathrm{CD} 4$ counts were indistinguishable from those with stable/increasing CD4 counts with respect to this measure of immune activation.

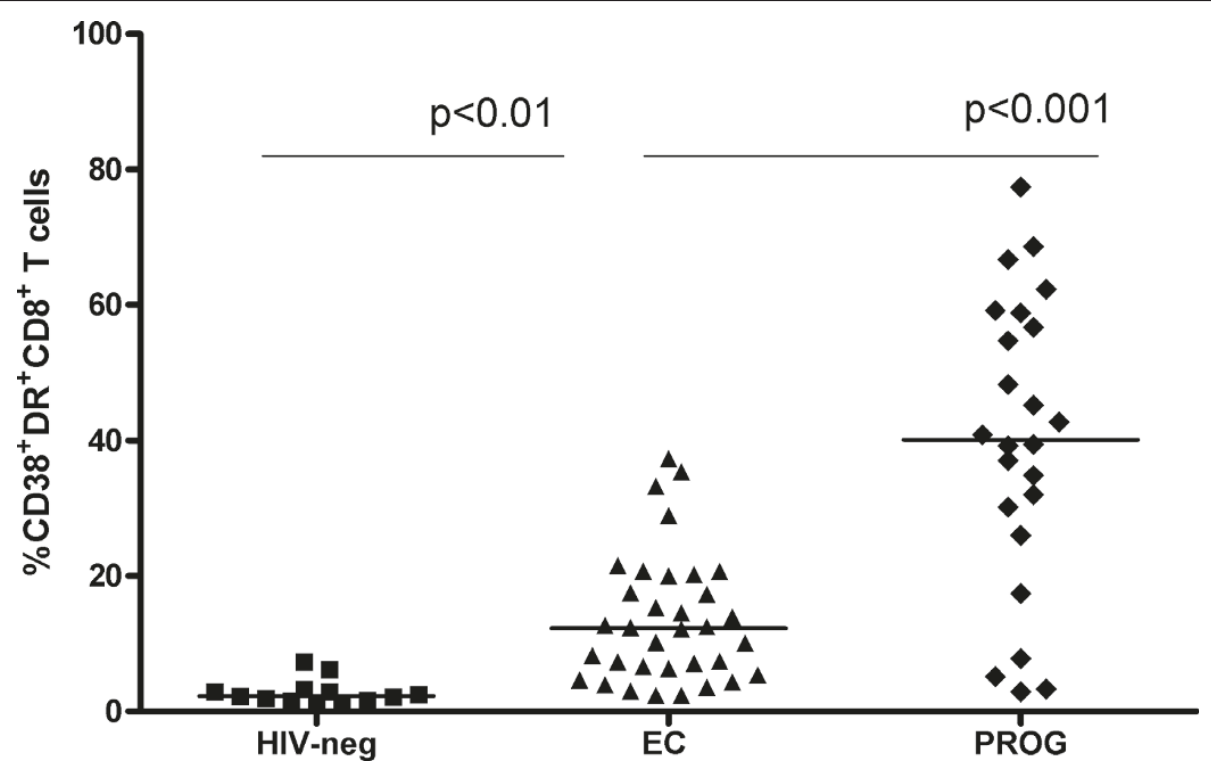

Figure 1 Distribution of $\mathrm{CD}^{+} \mathrm{T}$ cell activation markers among HIV uninfected healthy controls, HIV infected Elite Controllers (EC) and HIV infected progressors. Shown is a scatter plot of the percent of CD38 ${ }^{+} D R^{+} C D 8^{+} T$ cells in healthy controls (HIN-neg), HIV-infected EC (EC) and progressors (PROG). The line through each scatter plot indicates the median value for the group. The significance of between-group activation marker levels was assessed by comparing EC with healthy controls and with HIV infected progressors using a Kruskal-Wallis test with Dunn's multiple post-test comparisons. P-values shown correspond to comparisons performed between the 2 groups linked by the line under the p-values. 


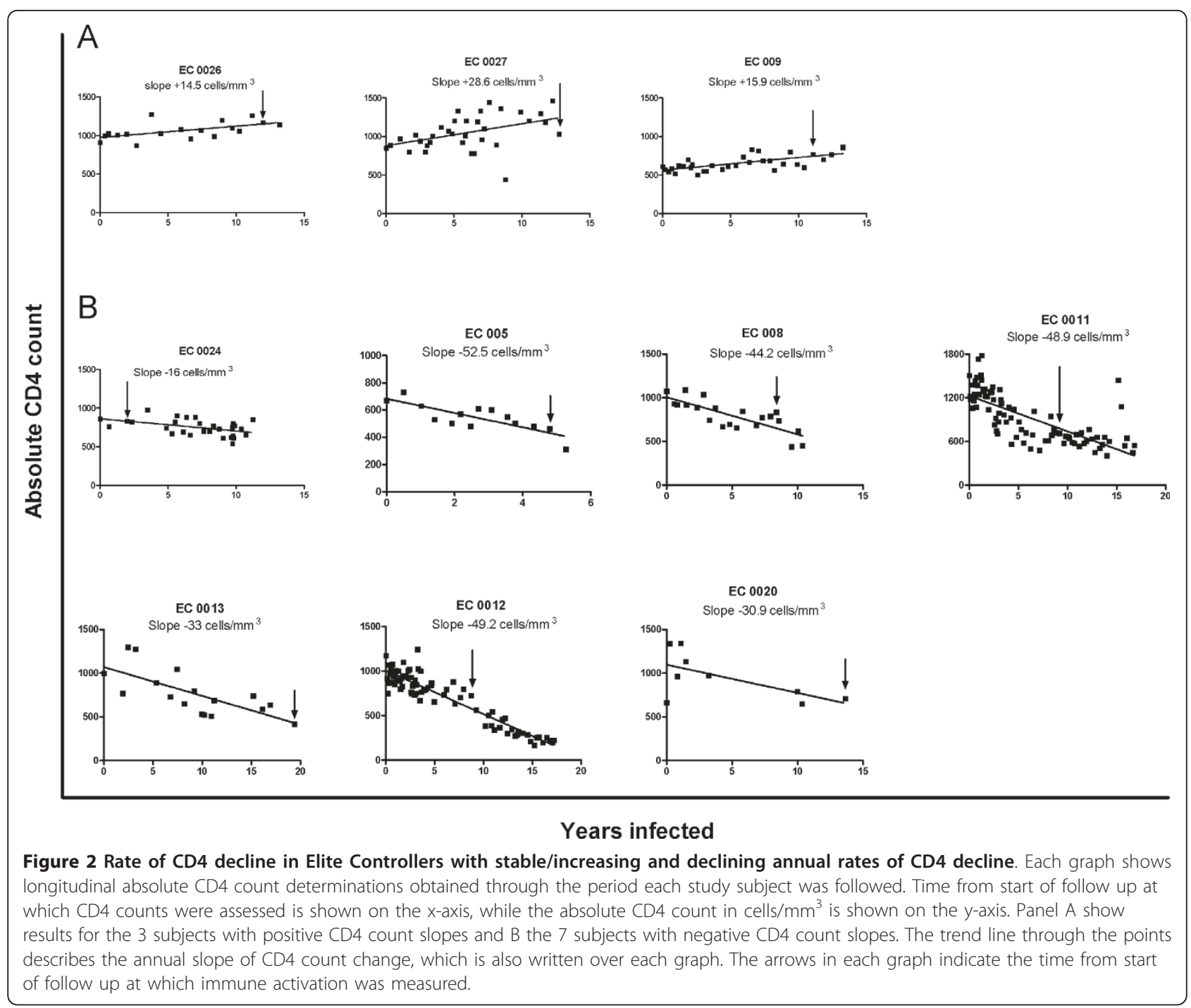

\section{Discussion}

We confirmed previous reports of elevated levels of CD8 + $\mathrm{T}$ cell immune activation among EC compared to healthy uninfected subjects $[8,16]$. EC with a declining CD4 counts did not have elevated percent $C D 8^{+} \mathrm{DR}$ ${ }^{+} \mathrm{CD} 8^{+} \mathrm{T}$ cell levels compared to those with stable or increasing CD4 counts.

High T-cell activation levels predict more rapid disease progression in untreated HIV infected individuals and decreased treatment mediated gains during anti-retroviral therapy independent of plasma HIV RNA levels [4,5,22-24]. The correlation between HIV VL and immune activation has made it difficult to resolve the relative contributions of immune activation independently of viremia on disease progression. Although spontaneous control of viremia predicts slower HIV disease progression, VL alone only explains a fraction of the variability in rate of HIV disease progression [25].
Even in EC, undetectable VL is not always accompanied by maintenance of CD4 counts above 500 cells/ $\mathrm{mm}^{3}$ and a stable CD4 count slope, suggesting that some EC are exhibiting evidence of HIV disease progression $[8,9,13,14,16,26,26,27]$. We hypothesized that in a setting of controlled viremia it would be possible to determine whether immune activation is driving the rate of CD4 count change. Although there have been several reports of EC exhibiting low or declining CD4 counts despite VL control to below the limit of detection of standard assays, the cross sectional nature of some of these analyses [8], small sample size $[9,16,26]$ and failure to take $95 \% \mathrm{CI}$ into consideration in assigning a negative value to the slope of CD4 count change [14,27] may have limited their ability to determine whether immune activation is driving CD4 decline. The results presented here add to this body of knowledge by reporting that in a group of $25 \mathrm{EC}$ with a median (range) follow up time 


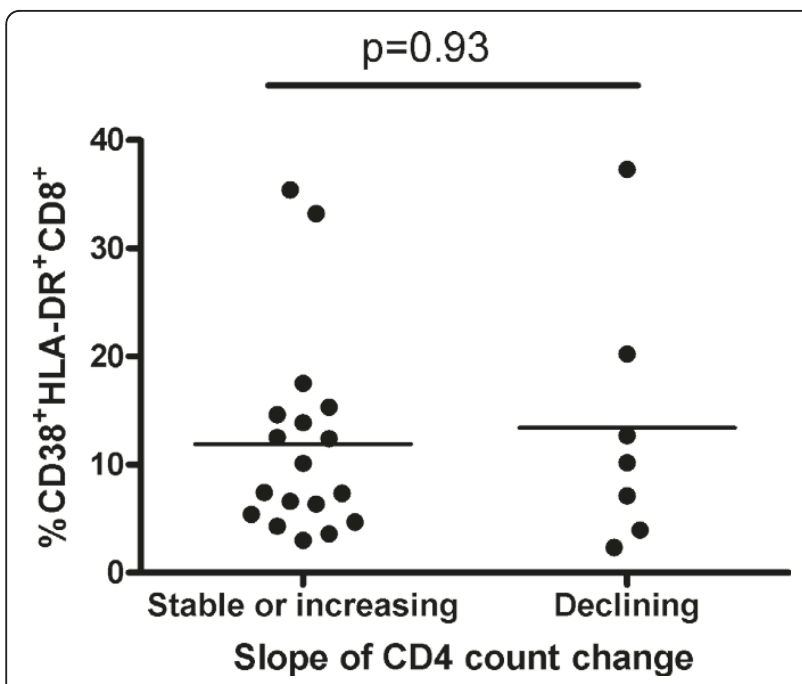

Figure 3 Percent of $C D 38^{+} \mathrm{DR}^{+} \mathrm{CD} 8^{+} \mathrm{T}$ cells does not distinguish Elite Controllers with stable/increasing versus declining CD4 counts. Shown is a scatter plot comparing the percent of CD38 ${ }^{+} \mathrm{HLA}-\mathrm{DR}^{+} \mathrm{CD} 8^{+} \mathrm{T}$ cells in the EC group with stable or increasing versus decreasing CD4 counts. The bar through each scatter plot indicates the median value for the group. P-values shown correspond to between-group comparisons performed using a Mann-Whitney test.

of $10(1,20)$ yrs and $18(4,86)$ CD4 count determinations 7 (28\%) EC exhibited a negative slope of CD4 count change. Since those with declining CD4 counts did not have higher levels of immune activation than those with stable or increasing CD4 counts our results support the interpretation that the level of immune activation as determined by the percent of $\mathrm{CD} 38^{+} \mathrm{DR}^{+} \mathrm{CD} 8^{+} \mathrm{T}$ cell levels is not high enough in EC to drive CD4 decline.

Recently, it has been observed that most EC have lowlevel viremia detected by assays that are more sensitive than the standard VL assays [27-29]. A limitation of the results reported here is that we do not have access to sufficient volumes of plasma from these subjects to obtain information on VL levels using more sensitive assays detecting VL levels below 50 copies/ml plasma to address this point. Therefore we cannot rule out that low level VL may be a determinant of immune activation as measured by assessment of percent $\mathrm{CD} 38^{+} \mathrm{DR}^{+} \mathrm{CD} 8^{+} \mathrm{T}$ cells.

In summary, despite VL control, EC have higher $\mathrm{CD} 8^{+}$ $\mathrm{T}$ cell activation levels than uninfected healthy controls. Some EC have declining CD4 counts and thus appear to be exhibiting HIV disease progression. Immune activation as determined by percent $\mathrm{CD} 38^{+} \mathrm{HLA}-\mathrm{DR}{ }^{+} \mathrm{CD} 8^{+} \mathrm{T}$ cell levels in not higher in the EC subset with falling CD4 counts.

\section{Acknowledgements}

The authors wish to thank the study participants of the Montreal Slow Progressor and Primary Infection cohorts and Mr. Mario Legault and Ms
Stephanie Matte, the coordinators for these respective cohorts. We also thank Drs. Joe Cox, Julian Falutz, Danielle Legault, Danielle Longpré, Danielle Rouleau, Martin Potter, Richard Lalonde, John MacLeod, Marina Klein, Serge Dufresne, Marc-André Charron. Michel Boissonnault, Sylvie Vézina, Annie Talbot, Mark Connors and Stephen Migueles who recruited and followed participants included in this study. We acknowledge the expert technical support of Ms. Marie-Pierre Boisvert, Ms. Nancy Simic, Mr. Saied Sharafi and Mr. Benjamin Tallon. This work was funded by the Réseau du SIDA et Maladies Infectueuses du Fonds de Recherche en Santé du Québec (FRSQ) and by a grant from the Canadian Institutes for Health Research \#HOP86862. SB was supported by a Ph.D scholarship from the FRSQ and J-P Routy is a scientific scholar receiving support from FRSQ.

\section{Author details}

${ }^{1}$ Research Institute of the McGill University Health Centre, Montréal, Québec, Canada. ${ }^{2}$ Division of Experimental Medicine, McGill University, Montréal, Québec, Canada. ${ }^{3}$ Division of Clinical Immunology and Allergy, McGill University Health Centre, Montréal, Québec, Canada. ${ }^{4}$ Immunodeficiency Service and Division of Hematology, Royal Victoria Hospital, McGill University Health Center, Montreal, Quebec, Canada. ${ }^{5}$ Clinique L'Actuel, Montréal, Québec, Canada. ${ }^{6}$ Clinique du Quartier Latin, Montréal, Québec, Canada. ${ }^{7}$ Clinical Sciences Division and Department of Medicine, University of Toronto, Toronto, Ontario, Canada. ${ }^{8}$ Maple Leaf Clinic, Toronto, ON, Canada. ${ }^{9}$ Centre de Recherche du Centre Hospitalier de I'Université de Montréal, Montréal, Québec, Canada.

\section{Authors' contributions}

PK designed the study, designed and optimized the antibody panel, performed the experiments, analyzed the data and prepared the manuscript. CMT and SB aided in study design, and critical review of manuscript. CMS, $J P R, R T, P C, M R B, B L, R K, M O, C C$, and $C T$ followed the Elite controller subjects clinically and provided samples for this study. NFB designed the study and prepared manuscript.

All authors have read and approved the final manuscript.

\section{Competing interests}

The authors declare that they have no competing interests.

Received: 18 April 2011 Accepted: 16 June 2011

Published: 16 June 2011

\section{References}

1. Giorgi JV, Lyles RH, Matud JL, et al: Predictive value of immunologic and virologic markers after long or short duration of HIV-1 infection. J Acquir Immune Defic Syndr 2002, 29(4):346-55.

2. Grossman Z, Meier-Schellersheim M, Sousa AE, Victorino RM, Paul WE: CD4+ T-cell depletion in HIV infection: are we closer to understanding the cause? Nat Med 2002, 8(4):319-23.

3. Giorgi JV, Hultin LE, McKeating JA, et al: Shorter survival in advanced human immunodeficiency virus type 1 infection is more closely associated with $\mathrm{T}$ lymphocyte activation than with plasma virus burden or virus chemokine coreceptor usage. J Infect Dis 1999, 179(4):859-70.

4. Liu Z, Cumberland WG, Hultin LE, Kaplan AH, Detels R, Giorgi JV: CD8+ Tlymphocyte activation in HIV-1 disease reflects an aspect of pathogenesis distinct from viral burden and immunodeficiency. J Acquir Immune Defic Syndr Hum Retrovirol 1998, 18(4):332-40.

5. Liu Z, Cumberland WG, Hultin LE, Prince HE, Detels R, Giorgi JV: Elevated CD38 antigen expression on CD8+ $T$ cells is a stronger marker for the risk of chronic HIV disease progression to AIDS and death in the Multicenter AIDS Cohort Study than CD4+ cell count, soluble immune activation markers, or combinations of HLA-DR and CD38 expression. J Acquir Immune Defic Syndr Hum Retrovirol 1997, 16(2):83-92.

6. Deeks SG, Kitchen CM, Liu L, et al: Immune activation set point during early HIV infection predicts subsequent CD4+ T-cell changes independent of viral load. Blood 2004, 104(4):942-7.

7. Deaglio S, Mehta K, Malavasi F: Human CD38: a (r)evolutionary story of enzymes and receptors. Leuk Res 2001, 25(1):1-12.

8. Hunt PW, Brenchley J, Sinclair $E$, et al: Relationship between $T$ cell activation and CD4+ T cell count in HIV-seropositive individuals with undetectable plasma HIV RNA levels in the absence of therapy. J Infect Dis 2008, 197(1):126-33. 
9. Sedaghat AR, Rastegar DA, O'Connell KA, Dinoso JB, Wilke CO, Blankson JN: T cell dynamics and the response to HAART in a cohort of HIV-1infected elite suppressors. Clin Infect Dis 2009, 49(11):1763-6.

10. Deeks SG, Walker BD: Human immunodeficiency virus controllers: mechanisms of durable virus control in the absence of antiretroviral therapy. Immunity 2007, 27(3):406-16.

11. Lambotte O, Boufassa F, Madec Y, et al: HIV controllers: a homogeneous group of HIV-1-infected patients with spontaneous control of viral replication. Clin Infect Dis 2005, 41(7):1053-6.

12. Migueles SA, Sabbaghian MS, Shupert WL, et al: HLA B*5701 is highly associated with restriction of virus replication in a subgroup of HIVinfected long term nonprogressors. Proc Natl Acad Sci USA 2000, 97(6):2709-14.

13. Okulicz JF, Marconi VC, Landrum ML, et al: Clinical outcomes of elite controllers, viremic controllers, and long-term nonprogressors in the US Department of Defense HIV natural history study. J Infect Dis 2009, 200(11):1714-23.

14. Madec Y, Boufassa F, Porter K, Meyer L: Spontaneous control of viral load and CD4 cell count progression among HIV-1 seroconverters. AIDS 2005, 19(17):2001-7.

15. Grabar S, Selinger-Leneman H, Abgrall S, Pialoux G, Weiss L, Costagliola D: Prevalence and comparative characteristics of long-term nonprogressors and HIV controller patients in the French Hospital Database on HIV. AIDS 2009, 23(9):1163-9.

16. Andrade A, Bailey JR, Xu J, et al: CD4+ T cell depletion in an untreated HIV type 1-infected human leukocyte antigen-B*5801-positive patient with an undetectable viral load. Clin Infect Dis 2008, 46(8):e78-e82.

17. Greenough TC, Sullivan JL, Desrosiers RC: Declining CD4 T-cell counts in a person infected with nef-deleted HIV-1. N Engl J Med 1999, 340(3):236-7.

18. Saez-Cirion A, Lacabaratz C, Lambotte O, et al: HIV controllers exhibit potent CD8 T cell capacity to suppress HIV infection ex vivo and peculiar cytotoxic T lymphocyte activation phenotype. Proc Natl Acad Sci USA 2007, 104(16):6776-81.

19. Andrade A, Bailey JR, Xu J, et al: CD4+ T cell depletion in an untreated HIV type 1-infected human leukocyte antigen-B*5801-positive patient with an undetectable viral load18. Clin Infect Dis 2008, 46(8):e78-e82.

20. Boulassel MR, Spurll G, Rouleau D, et al: Changes in immunological and virological parameters in HIV-1 infected subjects following leukapheresis. J Clin Apher 2003, 18(2):55-60.

21. Sousa AE, Carneiro J, Meier-Schellersheim M, Grossman Z, Victorino RM: CD4 T cell depletion is linked directly to immune activation in the pathogenesis of HIV-1 and HIV-2 but only indirectly to the viral load. J Immunol 2002, 169(6):3400-6.

22. Gandhi RT, Spritzler J, Chan E, et al: Effect of baseline- and treatmentrelated factors on immunologic recovery after initiation of antiretroviral therapy in HIV-1-positive subjects: results from ACTG 384. J Acquir Immune Defic Syndr 2006(4):426-34.

23. Goicoechea M, Smith DM, Liu L, et al: Determinants of CD4+ T cell recovery during suppressive antiretroviral therapy: association of immune activation, T cell maturation markers, and cellular HIV-1 DNA. J Infect Dis 2006, 194(1):29-37.

24. Hunt PW, Martin JN, Sinclair E, et al: T cell activation is associated with lower CD4+ T cell gains in human immunodeficiency virus-infected patients with sustained viral suppression during antiretroviral therapy. J Infect Dis 2003, 187(10):1534-43.

25. Rodriguez B, Sethi AK, Cheruvu VK, et al: Predictive value of plasma HIV RNA level on rate of CD4 T-cell decline in untreated HIV infection. JAMA 2006, 296(12):1498-506.

26. Greenough TC, Sullivan JL, Desrosiers RC: Declining CD4 T-cell counts in a person infected with nef-deleted HIV-1. N Engl J Med 1999, 340(3):236-7.

27. Pereyra F, Palmer S, Miura T, et al: Persistent low-level viremia in HIV-1 elite controllers and relationship to immunologic parameters. J Infect Dis 2009, 200(6):984-90.

28. Dinoso JB, Kim SY, Siliciano RF, Blankson JN: A comparison of viral loads between HIV-1-infected elite suppressors and individuals who receive suppressive highly active antiretroviral therapy. Clin Infect Dis 2008, 47(1):102-4.

29. Hatano H, Delwart EL, Norris PJ, et al: Evidence for persistent low-level viremia in individuals who control human immunodeficiency virus in the absence of antiretroviral therapy. J Virol 2009, 83(1):329-35. doi:10.1186/1742-6405-8-20

Cite this article as: Kamya et al:: T cell Activation does not drive CD4 decline in longitudinally followed HIV-infected Elite Controllers. AIDS Research and Therapy 2011 8:20.

\section{Submit your next manuscript to BioMed Central and take full advantage of:}

- Convenient online submission

- Thorough peer review

- No space constraints or color figure charges

- Immediate publication on acceptance

- Inclusion in PubMed, CAS, Scopus and Google Scholar

- Research which is freely available for redistribution

Submit your manuscript at www.biomedcentral.com/submit
Biomed Central 